\title{
Expeditive synthesis of trithiotriazine-cored glycoclusters and inhibition of Pseudomonas aeruginosa biofilm formation
}

\author{
Meriem Smadhi ${ }^{1,2}$, Sophie de Bentzmann ${ }^{*}$, Anne Imberty ${ }^{*}$, Marc Gingras ${ }^{5}$, \\ Raoudha Abderrahim ${ }^{2}$ and Peter G. Goekjian ${ }^{* 1}$
}

\section{Full Research Paper}

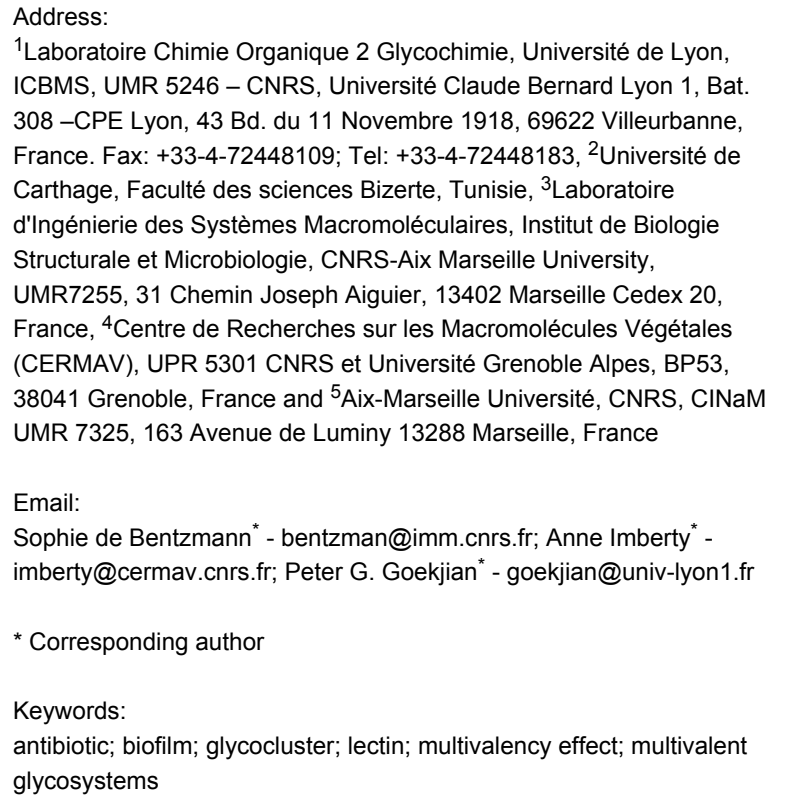

${ }^{1}$ Laboratoire Chimie Organique 2 Glycochimie, Université de Lyon, ICBMS, UMR 5246 - CNRS, Université Claude Bernard Lyon 1, Bat. 308 -CPE Lyon, 43 Bd. du 11 Novembre 1918, 69622 Villeurbanne, France. Fax: +33-4-72448109; Tel: +33-4-72448183, 2Université de Carthage, Faculté des sciences Bizerte, Tunisie, ${ }^{3}$ Laboratoire d'Ingénierie des Systèmes Macromoléculaires, Institut de Biologie Structurale et Microbiologie, CNRS-Aix Marseille University, UMR7255, 31 Chemin Joseph Aiguier, 13402 Marseille Cedex 20, France, ${ }^{4}$ Centre de Recherches sur les Macromolécules Végétales (CERMAV), UPR 5301 CNRS et Université Grenoble Alpes, BP53, 38041 Grenoble, France and ${ }^{5}$ Aix-Marseille Université, CNRS, CINaM UMR 7325, 163 Avenue de Luminy 13288 Marseille, France

Email:

Sophie de Bentzmann* - bentzman@imm.cnrs.fr; Anne Imberty* imberty@cermav.cnrs.fr; Peter G. Goekjian* - goekjian@univ-lyon1.fr

* Corresponding author

Keywords:

antibiotic; biofilm; glycocluster; lectin; multivalency effect; multivalent glycosystems

Beilstein J. Org. Chem. 2014, 10, 1981-1990. doi:10.3762/bjoc. 10.206

Received: 14 February 2014

Accepted: 30 July 2014

Published: 25 August 2014

This article is part of the Thematic Series "Multivalent glycosystems for nanoscience".

Guest Editor: B. Turnbull

(C) 2014 Smadhi et al; licensee Beilstein-Institut. License and terms: see end of document.

\begin{abstract}
Readily accessible, low-valency glycoclusters based on a triazine core bearing D-galactose and L-fucose epitopes are able to inhibit biofilm formation by Pseudomonas aeruginosa. These multivalent ligands are simple to synthesize, are highly soluble, and can be either homofunctional or heterofunctional. The galactose-decorated cluster shows good affinity for Pseudomonas aeruginosa lectin lecA. They are convenient biological probes for investigating the roles of lecA and lecB in biofilm formation.
\end{abstract}

\section{Introduction}

Pseudomonas aeruginosa (PA) is an opportunistic human pathogen known to cause a variety of hospital-borne infections. It poses a severe threat to immunocompromised patients, as well as to those suffering from cystic fibrosis or cancer [1-3]. Its virulence is largely associated with multi-resistance to antibi- otics, in particular due to the physical barrier created by surface-attached biofilms, thus limiting antibiotic penetration [4-6]. A challenging and useful task is therefore to develop novel strategies against PA colonies at this late stage of virulence. Among recent approaches, targeting biofilm formation or 
promoting its dissolution is thus particularly appealing. Because the formation of PA biofilm is a complex process partly mediated by the D-galactose-specific lectin lecA (PA-IL) [7-10] and the L-fucose-specific lectin lecB (PA-IIL) [11-13], lectin-carbohydrate interactions can provide a new target for pharmacological intervention. Further investigations of the specific functions played by these lectins in PA biofilm formation will provide useful understanding, and ultimately a means of prevention of PA virulence. The creative design of glycomimetics that can interfere or can modulate the bioactivity of these lectins in host recognition and adhesion in biofilm formation represents an attractive antibacterial strategy, as multivalent carbohydrate motifs on cell surfaces are known to mediate a broad range of cellular and tissue adhesion processes.

Carbohydrate recognition in biological systems is often based on the recognition of multiple epitopes through a synergistic and cooperative effect, called the "glycocluster effect" [14-16]. It has been shown in a number of systems that multivalency effects can be exploited to obtain high-avidity synthetic ligands against various types of lectins in the form of glycoclusters [17], poly(glycomer)s [18-21], and glycodendrimers [22-24]. In regards to PA, $C$-fucosylpeptide dendrimers were shown to inhibit biofilm formation and to efficiently disperse established biofilms in both reference and hospital strains of PA [25-27]. Recently, galactosylated peptide dendrimers have shown a strong affinity for lecA while inhibiting or dispersing biofilms $[28,29]$. This anti-biofilm effect mediated by glycodendrimers validates a new approach to the control PA propagation and infection.

In this work and following those lines, we had in mind to develop simpler, lower molecular weight, and hydrosoluble multivalent ligands against lecA and lecB, able to exert useful biofilm inhibition and to provide useful tools for investigating the roles of lecA and lecB in the colonization process. Our investigations further aimed at concentrating a high density of proximate carbohydrate epitopes with limited degrees of freedom onto a sulfurated heteroaromatic scaffold as novel glycosylated asterisk ligands [30]. We have thus designed a simple, yet effective new family of multivalent glycosylated architectures built around a trithiotriazine core. Both homo- and heterobifunctional ligands are obtained by a straightforward preparative route, as an innovative approach. Additionally, isothermal titration calorimetry (ITC) and dynamic light scattering (DLS) helped to better understand lectin-ligand interactions between lecA or lecB and these trithiotriazine-based ligands.

\section{Results and Discussion Design of ligands}

A previous study from our laboratories [30] has shown that lowvalent glycoasterisk ligands based on a persulfurated benzene core $[31,32]$ could have a dual role as a probe and as a ligand, due to their phosphorescence [33] and electrochemical properties [34] (Figure 1). They were also highly potent lectin

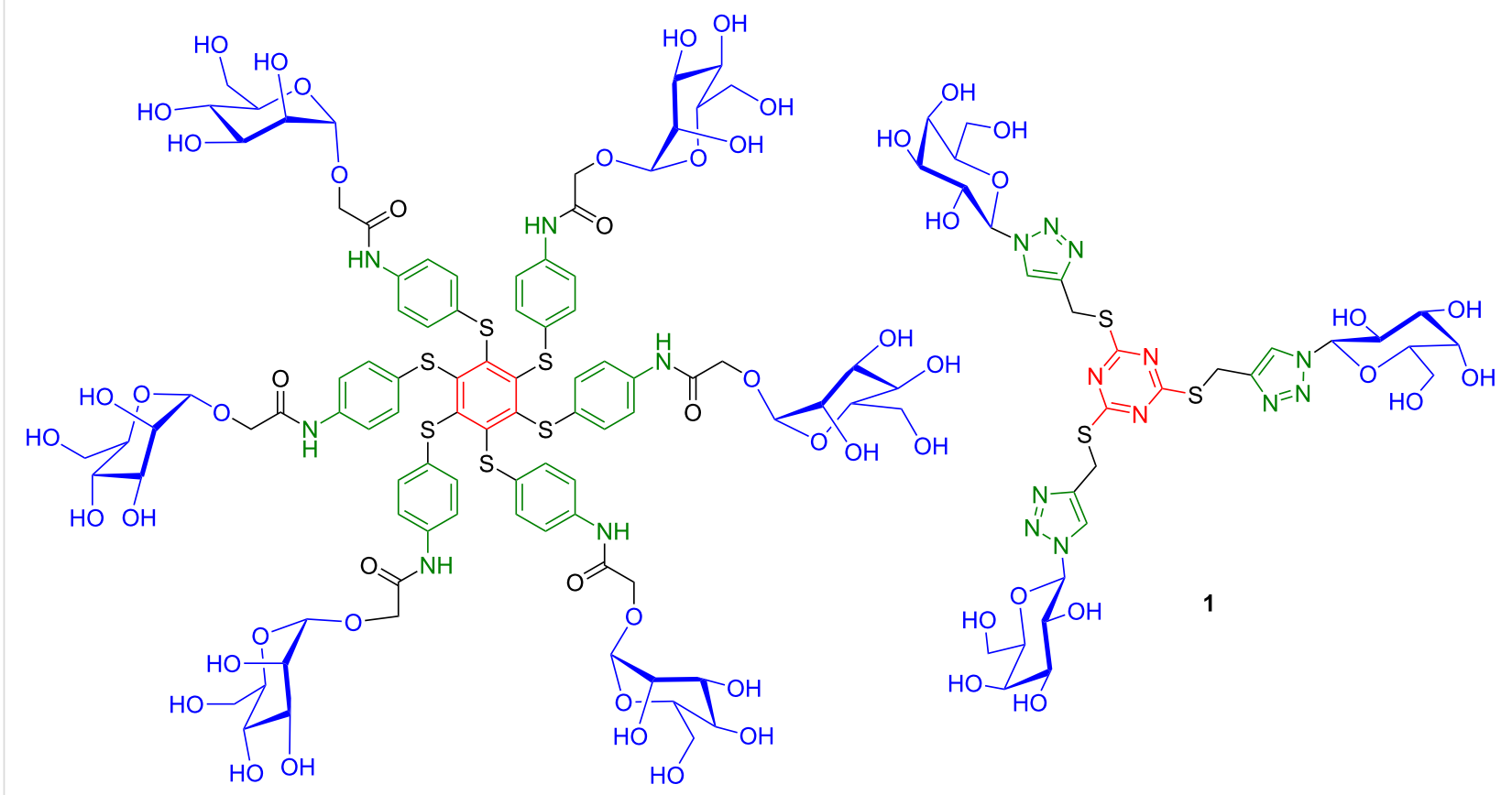

Figure 1: Previously reported low-valent glycoasterisk $\alpha-D-M a n$ ligand based on a persulfurated benzene core [30] and currenly reported $\beta$-D-Gal compound 1. 
aggregators. Among other aromatic glycoasterisks, Roy et al. described the synthesis of densely substituted hexaphenylbenzene glycoclusters [35].

In this work, we have designed a new family of low-valent glycoclusters based on a heteroaromatic core with the benefit of sulfur chemistry [36]. Sulfur facilitates the synthesis by providing a strong nucleophile and access to a thioether linkage under mild conditions, but it also enhances a number of potentially useful physical properties. For instance, polysulfuration of an aromatic core is known to significantly modify the HOMO-LUMO orbital energies, and thus change the redox potentials [31-34]. It also shifts the spectroscopic absorption and emission wavelengths and can lead to a phosphosrescence emission [33]. Additionally, an aza-aromatic core would improve water solubility by modifying $\pi-\pi$-interactions and by favoring hydrogen-bonding to water. These compounds also lack the hydrophobic peripheral benzene units of the previous glycoasterisk ligands. They were replaced with a methylenetriazole linker in order to increase water solubility and to modulate the degree of flexibility.

\section{Synthesis of ligands}

The glycoclusters were prepared from the inexpensive trithiocyanuric acid (1,3-5-triazine-2,4,6-trithiol) as the heteroaromatic core (Scheme 1). Trisubstitution of the commercial trisodium salt with propargyl bromide ensured the facile preparation of 2,4,6-tris(propargylthio)-1,3,5-triazine (2) as a key

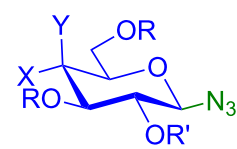

3: $R=R^{\prime}=A c$, $X=H, Y=O H(G a l)$

4: $\mathrm{R}=\mathrm{R}^{\prime}=\mathrm{Ac}$ $\mathrm{X}=\mathrm{OH}, \mathrm{Y}=\mathrm{H}(\mathrm{Glc})$

5: $\mathrm{R}=\mathrm{H}, \mathrm{R}^{\prime}=\mathrm{TBDMS}$,

$X=H, Y=O H(G a l)$

6: $R=H, R^{\prime}=B n$,

$X=\mathrm{OH}, \mathrm{Y}=\mathrm{H}(\mathrm{Glc})$

3,4

$\mathrm{MeONa}$

$\mathrm{MeOH}$

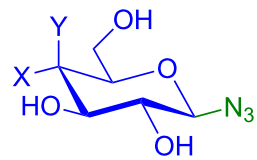

7: $\mathrm{X}=\mathrm{H}, \mathrm{Y}=\mathrm{OH}(\mathrm{Gal})$

8: $X=O H, Y=H(G l c)$
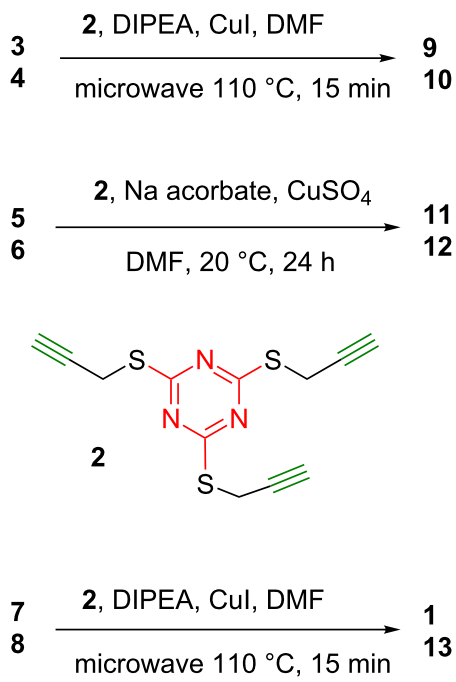

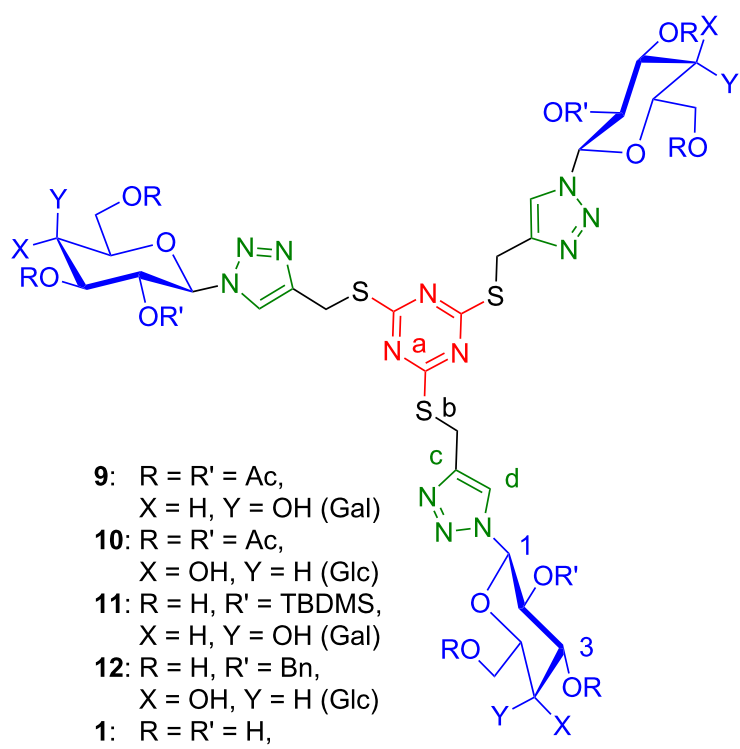

$X=H, Y=O H(G a l)$

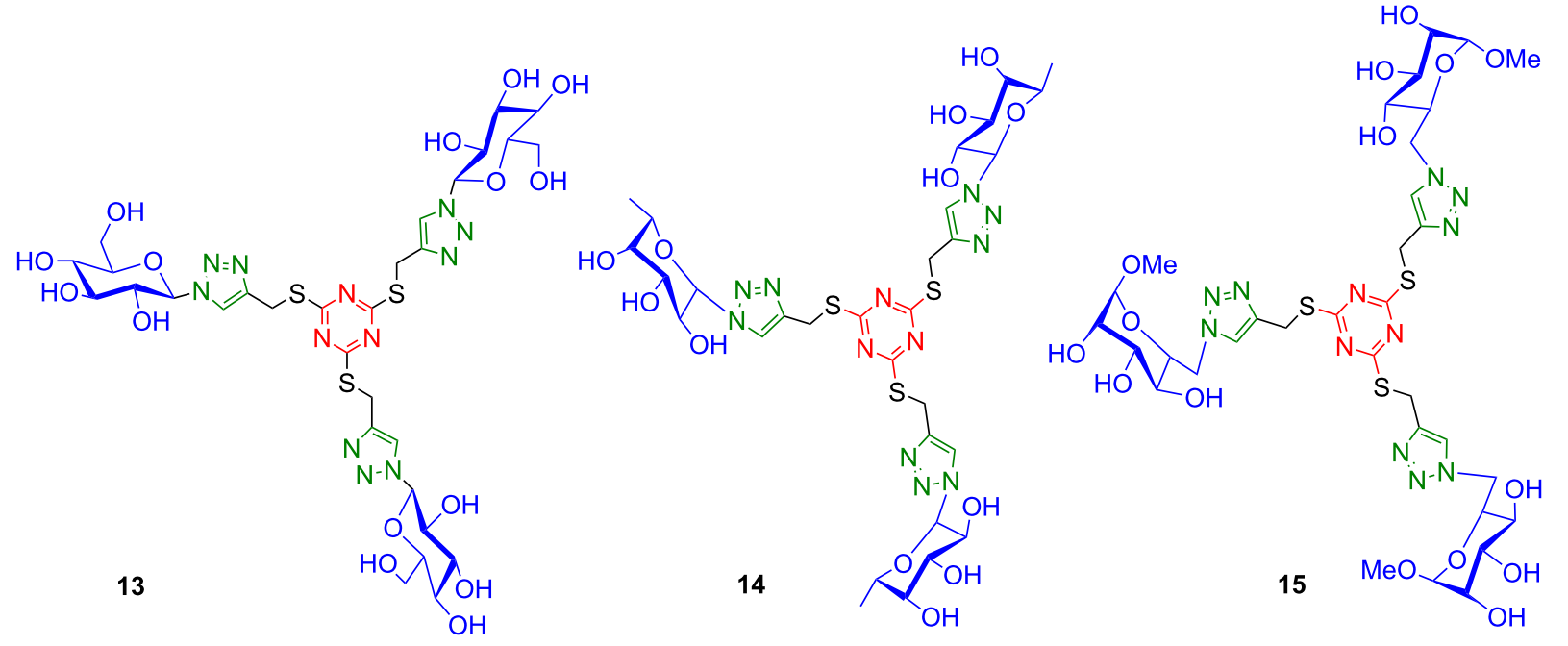


precursor [37]. The glycosyl units were incorporated via $\mathrm{Cu}(\mathrm{I})$ catalyzed Huisgen cycloaddition with protected or unprotected glycosyl azides.

We first investigated the Cu-catalyzed azide-alkyne cycloaddition $(\mathrm{CuAAC})$ of acetyl protected $\beta$-D-galactopyranosyl azide 3 [38], to tris(propargylthio)triazine 2, using $\mathrm{CuI}$ and diisopropylethylamine (DIPEA) in DMF under microwave irradiation at $110{ }^{\circ} \mathrm{C}$ for $15 \mathrm{~min}$. It provided the peracetylated D-galactopyanosyl cluster 9 in $73 \%$ yield. The peracetyl D-glucopyranosyl cluster $\mathbf{1 0}$ was similarly obtained in $92 \%$ yield.

The deacetylation of the carbohydrate units proved to be problematic, as a result of the instability of the triazine system under either forcing or mild Zemplén deprotection conditions. The tert-butyldimethylsilyl-protected galactopyranosyl azide $\mathbf{5}$ was therefore prepared via the epoxidation of silylated D-galactal with dimethyldioxirane (DMDO) generated in situ in the presence of a phase-transfer catalyst, followed by treatment with $\mathrm{NaN}_{3}$ [39]. This afforded the silyl-protected D-galactose trithiotriazine-triazole glycocluster 11 under $\mathrm{CuSO}_{4}$ /sodium ascorbate-catalyzed cycloaddition conditions [40] $\left(20^{\circ} \mathrm{C}, 24 \mathrm{~h}\right)$, in a satisfactory $87 \%$ yield. The benzyl protected D-glucose glycocluster 12 was similarly prepared from tri- $O$-benzyl- $\beta$-Dglucopyranosyl azide 6 [39] in $92 \%$ yield. The removal of the silyl groups with TBAF led to complete degradation of the scaffold. Ammonium fluoride in THF or trifluoroacetic acid also led to the fragmentation of the cluster core, which preceded complete deprotection of the carbohydrate groups. We were unable to obtain the deprotected glycoclusters by this route.

We therefore investigated a direct route to the glycoasterisks using unprotected azidosugars, thus avoiding the final deprotection step. The unprotected azidosugars were obtained by straightforward deprotection of the corresponding acetylprotected azides [38]. The trivalent glycoclusters decorated with D-galactose, 1, D-glucose, 13, and L-fucose, 14, epitopes were thus obtained directly in $53 \%, 50 \%$, and $44 \%$ yields, respectively, after reversed-phase chromatography. Methyl 6-azido-6deoxy- $\alpha$-D-mannoside was similarly coupled as a less expensive isostere of L-fucose [41]. The tris 6-C-(6-deoxy-Dmannosyl) cluster 15 was thus obtained in $47 \%$ yield. The cycloaddition conditions were optimized using 3.3 equiv of glycosyl azide [39] and one equivalent of tris(propargylthio)triazine 2 in DMF, catalyzed by CuI and DIPEA under microwave irradiation. The incorporation of three carbohydrate residues was established unambiguously by ESIMS, ${ }^{1} \mathrm{H}$ NMR, ${ }^{13} \mathrm{C} \mathrm{NMR}$, and $\mathrm{HMBC}$ analysis, in particular based on the symmetry of the molecule, and on the lack of signals corresponding to the residual alkynes in the NMR and MS. The connectivity was established thanks to $\mathrm{HMBC}^{3} J$ proton-carbon correlations between the anomeric proton of the sugar and the triazole methine carbon $(\mathrm{H}-1-\mathrm{C}-\mathrm{d})$, between the trizaole methine carbon and the thiomethylene protons (C-d-H-b), and between the thiomethylene protons and the triazine carbon (H-b-C-a). Despite the moderate yields, these products are readily accessible, being easy to purify, simple to characterize, and able to be produced on a relatively large scale.

The current process also offers the possibility of synthesizing mixed glycoclusters. Reducing the number of equivalents of glycosyl azide 7 to 2 equiv in the presence of $\mathrm{CuI}$ and DIPEA in $\mathrm{DMF}$ at $110{ }^{\circ} \mathrm{C}$ under microwave irradiation provided a statistical mixture with the bivalent cluster as the major product. The bis-D-galactosyl cluster 16 was thus isolated in $34 \%$ yield. A second $[3+2]$ cycloaddition with a different glycoside, such as D-glycopyranosyl azide $\mathbf{8}$, under the same conditions, provided for example the mixed $\mathrm{Gal}_{2}$-Glc triazine cluster 17 (Scheme 2).

The efficient conjugation of unprotected glycosyl azides to trithiotriazine 2 thus provides convenient access to low valency mono- or heterobifunctional glycoclusters. As expected, they display excellent aqueous solubility due of the combination of a dendritic polyheterocyclic architecture and carbohydrate epitopes.

\section{Biophysical studies}

Dynamic light scattering experiments (DLS) were performed on the trivalent and divalent galactose-substituted clusters 1, 16 and $\mathbf{1 7}$, as well as the glucose-substituted cluster $\mathbf{1 3}$ as a negative control. The results show that of the four clusters, only the divalent bis-D-Gal propargyl cluster 16 induces rapid aggregation of lecA (Figure 2 and Supporting Information File 1). Although such results should not be over-interpreted, they confirm that two epitopes are sufficient for aggregation, and suggest that additional hydrophobic and hydrophilic interactions play a role. The inability of these systems to efficiently aggregate lectins is in stark contrast to the hexavalent benzene cluster [30], which may be attributed to differences in rigidity and hydrophobicity between the two systems [25]. It thus appears that the direct diaryl sulfide bridge presents a more optimal degree of semi-rigidity.

The affinities of the designed glycoconjugates with lecA and lecB were determined by isothermal titration calorimetry (ITC) by addition of the ligands to a solution of lectin (Figure 3 ). Dissociation constants $\left(K_{\mathrm{d}}\right)$ and thermodynamic parameters $(\Delta G, \Delta H,-T \Delta S)$ are listed in Table 1 , together with the experimental binding stoichiometry $(n)$, defined as the number of glycocluster ligands per monomer of lectin. 

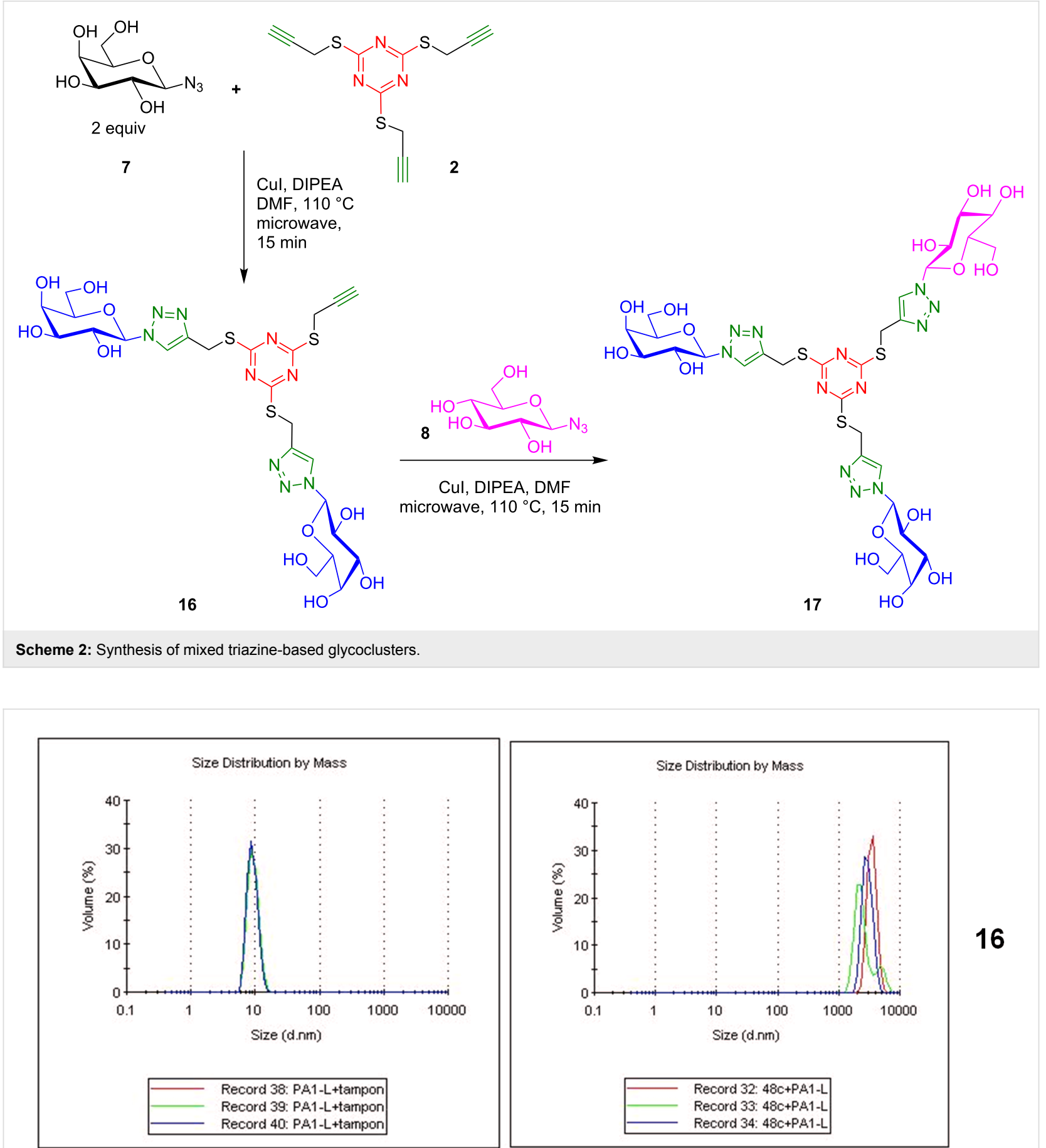

Figure 2: Dynamic light scattering experiments of bis-D-galactosyl proparyl cluster 16 with lecA. Distribution by mass for lecA + buffer (left) and lecA + $16(200 \mu \mathrm{M}$, right $)$ at 3 minute intervals. Additional experiments can be found in Supporting Information File 1.

The trivalent tris-galacosylated glycoconjugate 1 displays a good affinity and a $K_{\mathrm{d}}$ value of $1.09 \mu \mathrm{M}$, compared to $94 \mu \mathrm{M}$ for the monovalent reference, methyl $\beta$-D-galactoside (Table 1). The stoichiometry indicates that each cluster binds to three lecA sites. The tris-glucosylated cluster $\mathbf{1 3}$ was used as a negative control with nearly identical physical properties, and showed no affinity for the lectin, confirming that the recognition is epitopespecific. The bivalent clusters containing two galactose residues $\mathbf{1 6}$ and $\mathbf{1 7}$ have similar binding constants, although the mixed cluster 17 containing two D-galactose and one D-glucose residues provided better ITC titration curves and more rational $n$ values than the bis D-galactosyl monopropargyl cluster $\mathbf{1 6}$, 

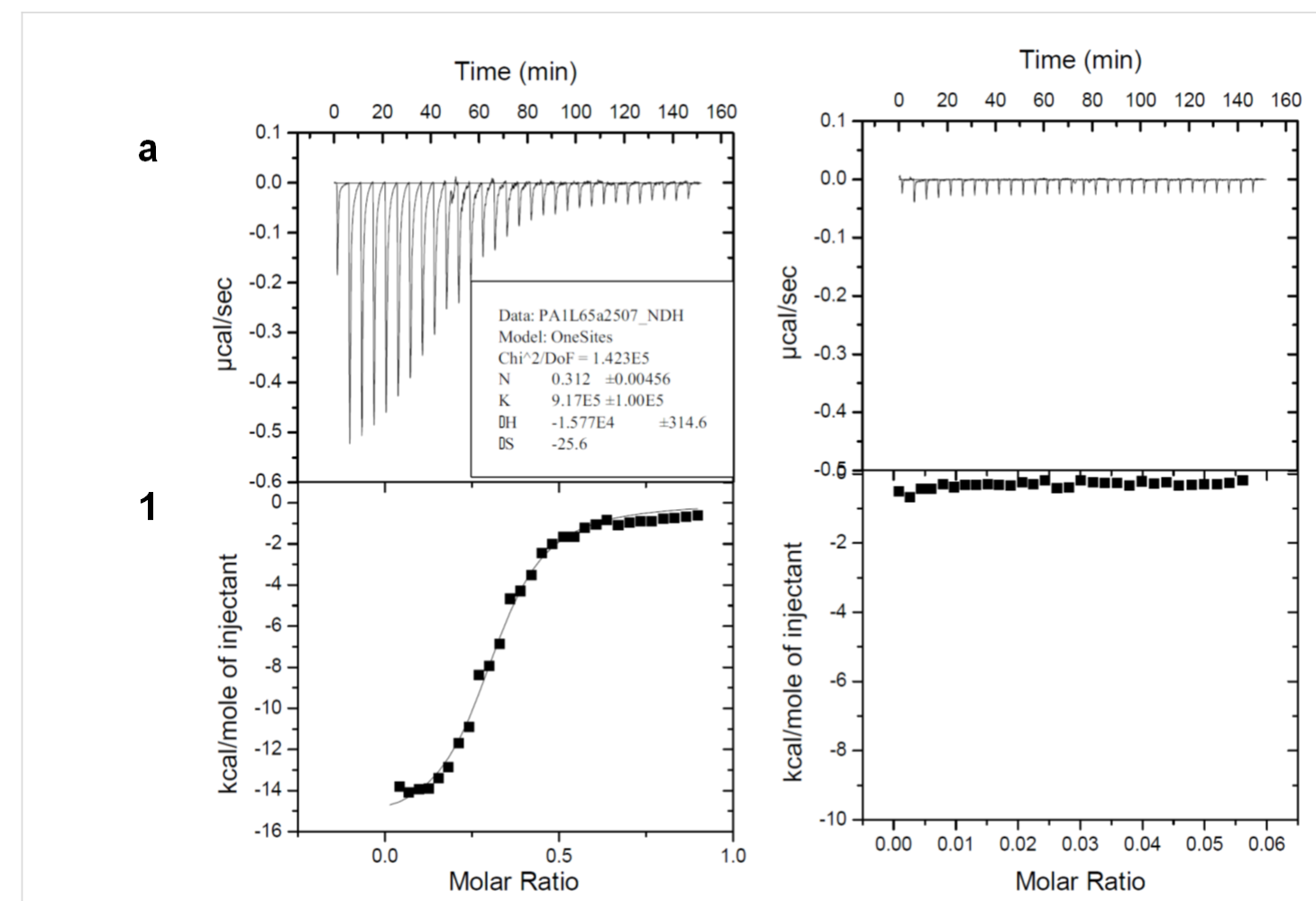

b

13

Figure 3: Typical ITC measurements representing the raw ITC data (top) and integrated titration curves (bottom) for the binding to lecA of a) tris-Dgalactosyl triazine cluster 1, and b) tris D-glucosyl glycocluster 13 (negative control).

\begin{tabular}{|c|c|c|c|c|c|c|c|}
\hline cmpd & val. & $n^{\mathrm{b}}$ & $\begin{array}{l}\Delta H \\
\mathrm{~kJ} / \mathrm{mol}\end{array}$ & $\begin{array}{l}-T \Delta S \\
\mathrm{~kJ} / \mathrm{mol}\end{array}$ & $\begin{array}{l}\Delta G \\
\mathrm{~kJ} / \mathrm{mol}\end{array}$ & $\begin{array}{l}K_{d} \\
\mu M\end{array}$ & $\beta / N^{c}$ \\
\hline$\beta-D-G a l O M e^{d}$ & 1 & 0.8 & -42.8 & 19.8 & -23.0 & 94 & 1 \\
\hline $\mathrm{Gal}_{3}$-tzn, 1 & 3 & 0.31 & -66.0 & 31.9 & -34.1 & 1.09 & 29 \\
\hline $\mathrm{Gal}_{2}$ Glc-tzn, 17 & 2 & 0.54 & -51.0 & 19.7 & -31.3 & 3.4 & 14 \\
\hline $\mathrm{Gal}_{2} \mathrm{Pg}$-tzn, 16 & 2 & 0.79 & -47.6 & 17.2 & -30.5 & 4.4 & 11 \\
\hline $\mathrm{Glc}_{3}$-tzn, 13 & 3 & & & & $<0$ & & \\
\hline
\end{tabular}

${ }^{\mathrm{a}} T=298 \mathrm{~K}$. ${ }^{\mathrm{b}}$ Stoichiometry. ${ }^{\mathrm{C}} \mathrm{mmprovement}$ in affinity relative to the methyl glycoside, divided by the valency. ${ }^{\mathrm{d} D a t a}$ from reference [50]. Pg $=$ propargyl; tzn = tris(triazolylmehylthio)triazine.

which may reflect precipitation of the lectin-cluster complex during the ITC experiment in the latter case, based on the DLS results above.

The observed $\beta / \mathrm{N}$ values in Table 1 , which reflect the relative affinity per unit sugar, are 29 for the trivalent cluster and in the range of 12 for the bivalent clusters. These values most likely reflect sub-site binding by the heterocyclic rings. Indeed, the divalent clusters $\mathbf{1 6}$ and $\mathbf{1 7}$ show a relatively less unfavorable entropy contribution, compared to methyl $\beta$-D-galactopyranoside, which is consistent with the contribution of additional hydrophobic interactions. No chelate binding is expected in this first generation cluster, as the arm length is well below the $29 \AA$ distance between sugar binding sites [7]. Not unexpectedly, several reported multivalent clusters have achieved higher affinities, yet the values observed here fall within the range obtained with far more complex multivalent systems [28,4250]. The $\beta$-fucoside-containing trivalent cluster 14 was also tested by ITC and a $K_{\mathrm{d}}$ of $50 \mu \mathrm{M}$ was obtained, which is significantly higher than the $K_{\mathrm{d}}$ for $\alpha$-MeFuc $(0.43 \mu \mathrm{M})$ [41] (data not shown). This confirms that lecB has lower affinity for $\beta$-fucosides than for the $\alpha$-anomers, but the trimeric $\beta$-fucoside cluster 14 still demonstrated reasonable binding. The 6-deoxymannose isostere $\mathbf{1 5}$ was not tested, in view of the low affinity of the 
$\beta$-fucose epitopes. These clusters thus represent a readily accessible, highly soluble, and convenient tool for the investigation of the role of lecA and lecB in the formation of biofilms by Pseudomonas aeruginosa.

\section{Inhibition of biofilm formation}

While the expectation that glycoclusters with high affinity to lec $\mathrm{A}$ and lecB should inhibit biofilm formation is now a common design hypothesis, it is nonetheless important to show whether individual synthetic clusters do so in fact. This has only been done in a limited number of examples $[9,10]$, perhaps due to lack of solubility, lack of availability, or other reasons. The response of PA biofilms to different clusters is not necessarily directly correlated to their affinity, as many other factors may intervene, and the accumulation of biofilm data will therefore be an important factor in our understanding of this complex process.

The $P$. aeruginosa adherence assay was performed in 24 well microplates. Biofilms were obtained after $24 \mathrm{~h}$ of incubation at $30{ }^{\circ} \mathrm{C}$ in LB medium alone or in the presence or galactose, fucose, or glucose (control)-substituted trivalent clusters and stained with crystal violet $(\mathrm{CV})$.

A statistically significant reduction in biofilm formation was observed at $5 \mathrm{mM}$ concentration of either the galactose- or the fucose-bearing cluster, 1 and 14, respectively, as compared to the glucose-bearing cluster, 13, or absence of cluster (Figure 4). To check that differences observed were not due to bacterial growth defect in the presence of clusters, a growth inhibition control experiment was performed (Figure 4C). No growth defect was observed, further confirming that observed reduction of biofilm formation in the presence of the galactose or the fucose-bearing clusters is due to potential effects on P. aeruginosa lectins.

\section{Conclusion}

We have developed a convenient synthesis of simple, lowvalency glycoclusters. These compounds have good solubility, are readily accessible, and are easy to purify and to characterize. The presence of the sulfur provides beneficial structural and synthetic elements, and the heterocyclic systems improve solu-
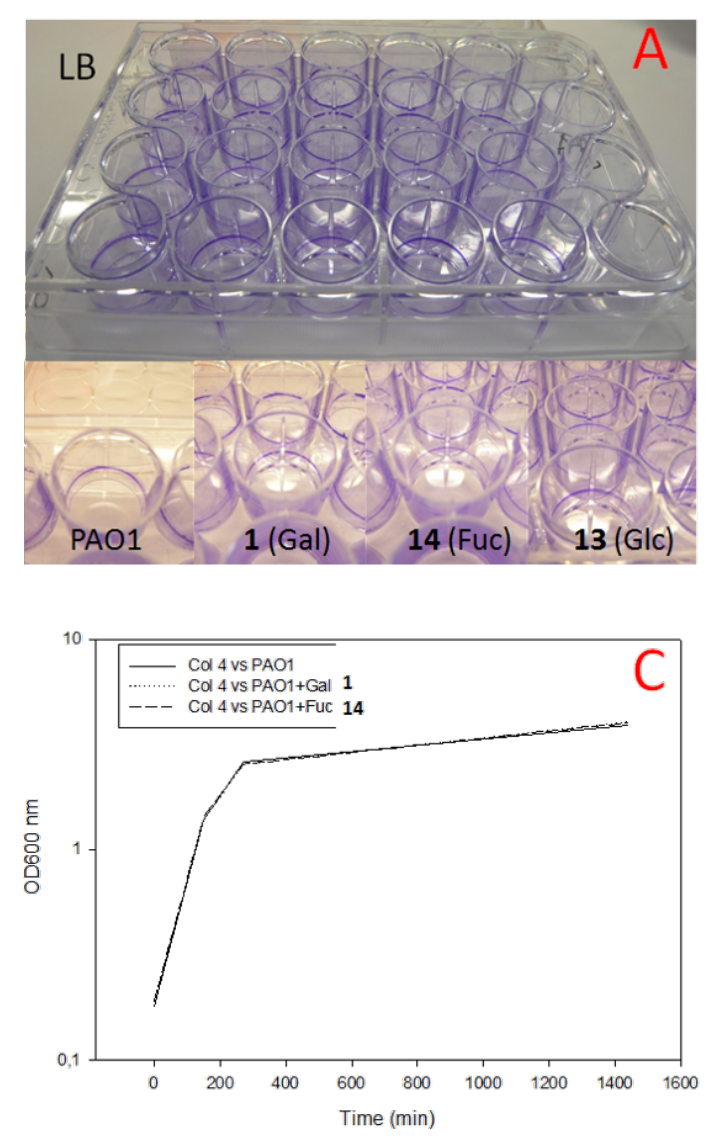
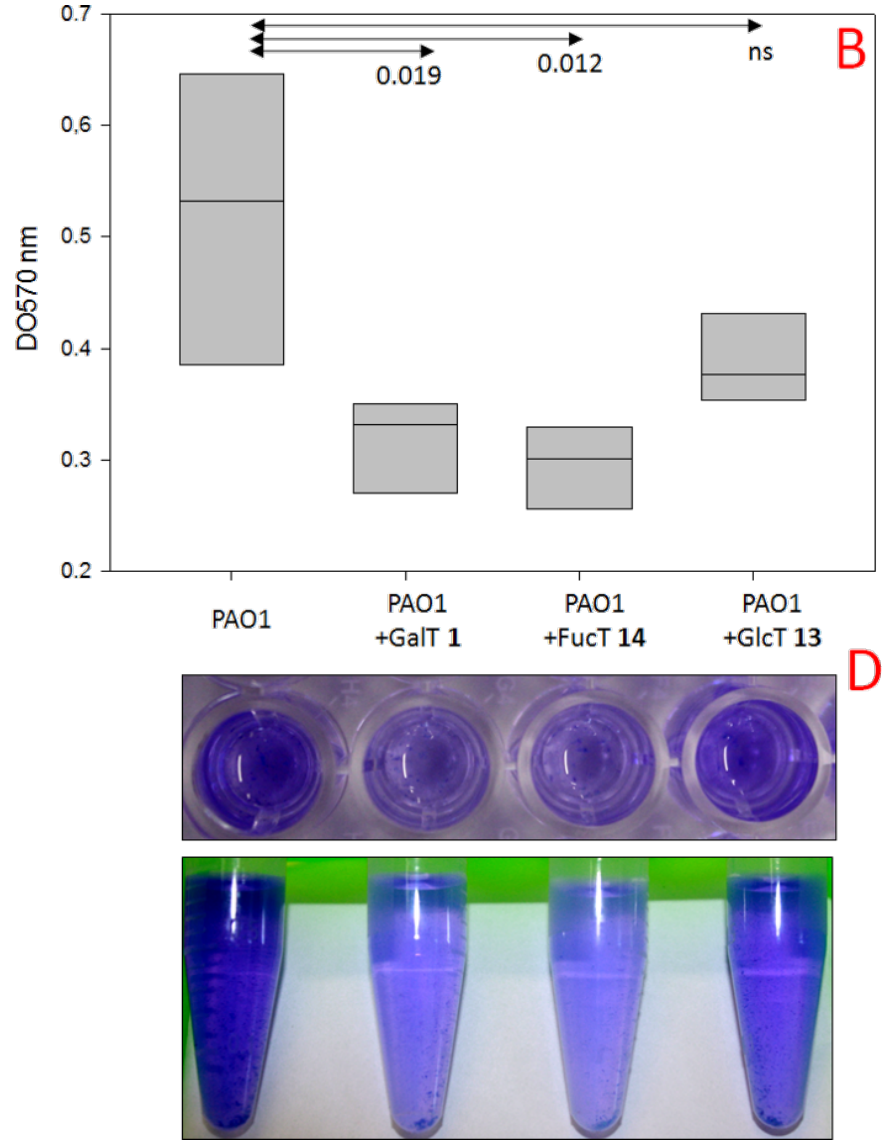

Figure 4: Inhibition of PAO1 biofilm formation by D-galactose cluster 1, L-fucose cluster 14, and D-glucose cluster 13 (negative control). A) Biofilm growth assay in LB medium. B) Statistical analysis (above, $n=5$, duplicate UV measurements) of ethanol-solubilized biofilm recovered from each well (below). C) PAO1 growth inhibition control test. 
bility and may potentially lead to better pharmacodynamic properties for eventual biological applications. They show good affinities for the lectins, comparable to more complex multivalent systems. The recognition is sugar-specific, as the corresponding D-glucose glycocluster shows no affinity for the lectin, and can thus be used as a negative control. Both the D-galactose and L-fucose clusters are able to inhibit biofilm formation. These compounds therefore provide convenient tools for further investigation of lectin-mediated processes in $P$. aeruginosa biofilm formation.

\section{Experimental}

2,4,6-tris(1-( $\beta$-D-galactopyranosyl)triazol-4-ylmethylthio)1,3,5-triazine (1). A solution of compound $2(22 \mathrm{mg}$, $0.073 \mathrm{mmol}, 1$ equiv), $\beta$-D-galactopyranosyl azide $(59.7 \mathrm{mg}$, $0.294 \mathrm{mmol}, 4$ equiv), $\mathrm{CuI}$ ( $0.022 \mathrm{mmol}, 4.2 \mathrm{mg}, 0.3$ equiv) and DIPEA ( $0.2 \mathrm{~mL}, 15$ equiv) in DMF $(2 \mathrm{~mL})$ was heated under microwave irradiation for 15 minutes at $110{ }^{\circ} \mathrm{C}$. The reaction mixture was concentrated in vacuo and the residue was purified by $\mathrm{C} 18$ chromatography (Combiflash, Grace Reveleris C18 RP $4 \mathrm{~g}$ Cartridge, $\mathrm{H}_{2} \mathrm{O} / \mathrm{MeOH}$ gradient). Yield $=53 \%$. TLC (C18; $\left.\mathrm{MeOH} / \mathrm{H}_{2} \mathrm{O} 1: 1\right) \cdot R_{\mathrm{f}}=0.42 .[\alpha]_{\mathrm{D}}+14.5\left(c 1, \mathrm{H}_{2} \mathrm{O}\right)$; IR (neat) $v$ $=3287.6 \mathrm{~cm}^{-1}(\mathrm{OH}) 1474.3$ (triazole); ${ }^{1} \mathrm{H}$ NMR $(400 \mathrm{MHz}$, DMSO- $\left.d_{6}\right) \delta 8.20 \mathrm{ppm}(\mathrm{s}, 3 \mathrm{H}, \mathrm{H}-\mathrm{d}), 5.45(\mathrm{~d}, J=9.2 \mathrm{~Hz}, 3 \mathrm{H}$, $\mathrm{H}-1), 5.22$ (d, $J=6.0 \mathrm{~Hz}, 3 \mathrm{H}, \mathrm{OH}-2), 5.01$ (d, $J=5.7 \mathrm{~Hz}, 3 \mathrm{H}$, OH-3), 4.69 (t, 3H, OH-6), 4.64 (d, $J=5.4 \mathrm{~Hz}, 3 \mathrm{H}, \mathrm{OH}-4), 4.52$ (s, 6H, H-b), 4.01 (ddd, $J=9.3 \mathrm{~Hz}, J=9.2 \mathrm{~Hz}, J=6.0 \mathrm{~Hz}, 3 \mathrm{H}$, H-2), 3.76 (br dd, $J=5.7,3.4 \mathrm{~Hz}, 3 \mathrm{H}, \mathrm{H}-4$ ), 3.69 (br dd, $J=$ $6.1, J=6.1 \mathrm{~Hz}, 3 \mathrm{H}, \mathrm{H}-5), 3.55-3.44$ (m, 9H, H-3, H-6, H-6'); ${ }^{13} \mathrm{C}$ NMR (100 MHz, DMSO- $\left.d_{6}\right) \delta 178.5$ ppm (C-a), 142.4 (C-c), 122.5 (C-d), 88.1 (C-1), 78.4 (C-5), 73.6(C-3), 69.2 (C-2), 68.4 (C-4), 60.4 (C-6), 24.6 (C-b); HRMS-ESI ( $\mathrm{m} / \mathrm{z})$ : [M $+\mathrm{H}]^{+}$calcd for $\mathrm{C}_{30} \mathrm{H}_{43} \mathrm{~N}_{12} \mathrm{O}_{15} \mathrm{~S}_{3}$, 907.2170; found, 907.2127; $(m / z):[\mathrm{M}+\mathrm{Na}]^{+}$calcd for $\mathrm{C}_{30} \mathrm{H}_{43} \mathrm{~N}_{12} \mathrm{NaO}_{15} \mathrm{~S}_{3}, 929.1980$; found, 929.1947.

2,4,6-tris(1-( $\beta$-D-glucopyranosyl)triazol-4-ylmethylthio)1,3,5-triazine (13). A solution of compound $2(18.1 \mathrm{mg}$, $0.062 \mathrm{mmol}, 1$ equiv), $\beta$-D-glucopyranosyl azide (51 mg, $0.25 \mathrm{mmol}, 4$ equiv), $\mathrm{CuI}$ ( $3.5 \mathrm{mg}, 0.3$ equiv) and DIPEA $(0.74 \mathrm{mmol}, 0.16 \mathrm{~mL}, 15$ equiv) in DMF $(1 \mathrm{~mL})$ was heated under microwave irradiation for 15 minutes at $110^{\circ} \mathrm{C}$. The reaction mixture was concentrated in vacuo and the residue was purified by $\mathrm{C} 18$ chromatography (Combiflash, Grace Reveleris C18 RP 4g Cartridge, $\mathrm{H}_{2} \mathrm{O} / \mathrm{MeOH}$ gradient). Yield $=50 \%$. TLC $\left(\mathrm{C} 18 ; \mathrm{MeOH} / \mathrm{H}_{2} \mathrm{O} 1: 1\right) \cdot R_{\mathrm{f}}=0.47 .[\alpha]_{\mathrm{D}}-2.0\left(c 0.46, \mathrm{H}_{2} \mathrm{O}\right) ;{ }^{1} \mathrm{H}$ NMR (300 MHz, DMSO- $\left.d_{6}\right) \delta 8.25$ ppm (s, 3H, H-d), 5.51 (d, $J$ $=9.3 \mathrm{~Hz}, 3 \mathrm{H}, \mathrm{H}-1), 5.38(\mathrm{~d}, J=6.0 \mathrm{~Hz}, 3 \mathrm{H}, \mathrm{OH}-2), 5.27(\mathrm{~d}, J=$ $4.9,3 \mathrm{H}, \mathrm{OH}-3), 5.14(\mathrm{~d}, J=5.5,3 \mathrm{H}, \mathrm{OH}-4), 4.63(\mathrm{t}, J=5.6$, $3 \mathrm{H}, \mathrm{OH}-6), 4.52$ (s, 6H, H-b), 3.77-3.66 (m, 6H, H-2, H-6), 3.46-3.32 (m, 6H, H-3, H-5, H-6'), 3.25-3.15 (m, 3H, H-4);
${ }^{13} \mathrm{C}$ NMR (75 MHz, DMSO- $\left.d_{6}\right) \delta 178.6 \mathrm{ppm}(\mathrm{C}-\mathrm{a}), 142.4$ (C-c), 122.9 (C-d), 87.5 (C-1), 79.9 (C-3), 76.9 (C-5), 72.0 (C-2), 69.5 (C-4), 60.7 (C-6), 24.6 (C-b); HRMS-ESI $(\mathrm{m} / \mathrm{z})$ : $[\mathrm{M}+\mathrm{H}]^{+}$ calcd for $\mathrm{C}_{30} \mathrm{H}_{43} \mathrm{~N}_{12} \mathrm{O}_{15} \mathrm{~S}_{3}$, 907.2132; found, 907.2127; ( $\left.\mathrm{m} / \mathrm{z}\right)$ : $[\mathrm{M}+\mathrm{Na}]^{+}$calcd for $\mathrm{C}_{30} \mathrm{H}_{43} \mathrm{~N}_{12} \mathrm{NaO}_{15} \mathrm{~S}_{3}$. 929.1943; found, 929.1947.

\section{2,4,6-tris(1-( $\beta$-L-fucopyranosyl)triazol-4-ylmethylthio)-} 1,3,5-triazine (14). Compound 2 (132.9 mg, $0.458 \mathrm{mmol}$, 1 equiv), $\beta$-L-fucopyranosyl azide $(345.6 \mathrm{mg}, 1.82 \mathrm{mmol}$, 4 equiv), $\mathrm{CuI}$ ( $26 \mathrm{mg}, 0.13 \mathrm{mmol}, 0.3$ equiv) and DIPEA (1.13 mL, $16.8 \mathrm{mmol}, 5$ equiv) in DMF $(2 \mathrm{~mL})$ was heated under microwave irradiation for 15 minutes at $110{ }^{\circ} \mathrm{C}$. The reaction mixture was concentrated in vacuo and the residue was purified by $\mathrm{C} 18$ chromatography (Combiflash, Grace Reveleris C18 RP 4g Cartridge, $\mathrm{H}_{2} \mathrm{O} / \mathrm{MeOH}$ gradient). Yield $=44 \%$. TLC $\left(\mathrm{C} 18 ; \mathrm{MeOH} / \mathrm{H}_{2} \mathrm{O} 1: 1\right) R_{\mathrm{f}}=0.5 .[\alpha]_{\mathrm{D}}+5.2\left(c 0.17 ; \mathrm{H}_{2} \mathrm{O}\right) ;{ }^{1} \mathrm{H}$ NMR (400 MHz, DMSO- $\left.d_{6}\right) \delta 8.18$ ppm (s, 3H, H-d), 5.44 (d, $J$ $=9.2 \mathrm{~Hz}, 3 \mathrm{H}, \mathrm{H}-1), 5.22(\mathrm{~d}, J=6.0 \mathrm{~Hz}, 3 \mathrm{H}, \mathrm{OH}-2), 5.00(\mathrm{~d}, J$ $=5.5 \mathrm{~Hz}, 3 \mathrm{H}, \mathrm{OH}-3), 4.70(\mathrm{~d}, J=5.4 \mathrm{~Hz}, 3 \mathrm{H}, \mathrm{OH}-4), 4.52(\mathrm{~s}$, $6 \mathrm{H}, \mathrm{H}-\mathrm{b}$ ), 4.03-3.94 (m, 3H, H-2), 3.88 (br. q, $J=6.3 \mathrm{~Hz}, 3 \mathrm{H}$, H-5), 3.57-3.51 (m, 6H, H-4, H-3), 1.13 (d, $J=6.4 \mathrm{~Hz}, 9 \mathrm{H}$, $\left.\mathrm{CH}_{3}\right) ;{ }^{13} \mathrm{C}$ NMR $\left(100 \mathrm{MHz}, \mathrm{DMSO}-d_{6}\right) \delta 178.1 \mathrm{ppm}(\mathrm{C}-\mathrm{a})$, 142.0 (C-c), 122.0 (C-d), 87.6 (C-1), 73.6 (C-3), 73.0 (C-5), $71.0(\mathrm{C}-4), 68.5(\mathrm{C}-2), 24.3(\mathrm{C}-\mathrm{b}), 16.3\left(\mathrm{CH}_{3}\right)$; HRMS-ESI $(\mathrm{m} /$ $z$ ): $[\mathrm{M}+\mathrm{H}]^{+}$calcd for $\mathrm{C}_{30} \mathrm{H}_{43} \mathrm{~N}_{12} \mathrm{O}_{12} \mathrm{~S}_{3}, 859.2299$; found, $859.2280 ;(m / z):[\mathrm{M}+\mathrm{Na}]^{+}$calcd for $\mathrm{C}_{30} \mathrm{H}_{42} \mathrm{~N}_{12} \mathrm{NaO}_{12} \mathrm{~S}_{3}$, 881.2096; found, 881.2099.

\section{2,4-bis(1-( $\beta$-D-galactopyranosyl)triazol-4-ylmethylthio)-6-} (prop-2-ynylthio)-1,3,5-triazine (16). A solution of compound 2 (35.9 mg, $0.123 \mathrm{mmol}, 1$ equiv), $\beta$-D-galactopyranosyl azide (50.6 mg, $0.240 \mathrm{mmol}, 2$ equiv), $\mathrm{CuI}$ (0.036 mmol, $7 \mathrm{mg}$, 0.3 equiv) and DIPEA ( $1.84 \mathrm{mmol}, 0.32 \mathrm{~mL}, 15$ equiv) in DMF $(2 \mathrm{~mL})$ was heated under microwave irradiation for 15 minutes at $110{ }^{\circ} \mathrm{C}$. The reaction mixture was concentrated in vacuo and the residue was purified by $\mathrm{C} 18$ chromatography (Combiflash, Grace Reveleris C18 RP 4g Cartridge, $\mathrm{H}_{2} \mathrm{O} / \mathrm{MeOH}$ gradient). Yield $=34 \%$. $[\alpha]_{\mathrm{D}}+4.3\left(\mathrm{c} 0.36, \mathrm{H}_{2} \mathrm{O}\right) ;{ }^{1} \mathrm{H}$ NMR $(400 \mathrm{MHz}$, DMSO-d $\left.d_{6}\right) \delta .18 \mathrm{ppm}(\mathrm{s}, 2 \mathrm{H}, \mathrm{H}-\mathrm{d}), 5.44(\mathrm{~d}, J=9.2 \mathrm{~Hz}, 2 \mathrm{H}$, $\mathrm{H}-1$ ), 5.23 (d, $J=6.0 \mathrm{~Hz}, 2 \mathrm{H}, \mathrm{OH}-2), 5.02$ (d, $J=5.6 \mathrm{~Hz}, 2 \mathrm{H}$, OH-3), 4.70 (t, $J=5.6 \mathrm{~Hz}, 2 \mathrm{H}, \mathrm{OH}-6), 4.67$ (d, $J=5.3 \mathrm{~Hz}, 2 \mathrm{H}$, OH-4), 4.58-4.50 (AB, $J \sim 15.0 \mathrm{~Hz}, 4 \mathrm{H}, \mathrm{H}-\mathrm{b}), 4.05-4.03$ (m, $2 \mathrm{H}, \mathrm{H}-\mathrm{e}), 4.0$ (ddd, $J=9.3 \mathrm{~Hz}, J=9.2 \mathrm{~Hz}, J=6.0 \mathrm{~Hz}, 2 \mathrm{H}$, H-2), 3.76 (br dd, $J=5.3 \mathrm{~Hz}, J=3.5 \mathrm{~Hz}, 2 \mathrm{H}, \mathrm{H}-4$ ), 3.69 (br t, $J$ $=6.0 \mathrm{~Hz}, 2 \mathrm{H}, \mathrm{H}-5), 3.54-3.46(\mathrm{~m}, 6 \mathrm{H}, \mathrm{H}-3, \mathrm{H}-6, \mathrm{H}-6$ '), $3.23(\mathrm{t}$, $J=2.5 \mathrm{~Hz}, 1 \mathrm{H}, \mathrm{H}-\mathrm{g}) ;{ }^{13} \mathrm{C}$ NMR $\left(100 \mathrm{MHz}, \mathrm{DMSO}-d_{6}\right) \delta 178.4$ ppm (C-a), 177.8 (C-a'), 142.4 (C-c), 122.3 (C-d), 87.9 (C-1), 79.5 (C-f), 78.2 (C-5), 73.8 (C-g), 73.4 (C-3), 69.1 (C-2), 68.3 (C-4), 60.2 (C-6), 24.4 (C-b), 18.4 (C-e); HRMS-ESI ( $m / z)$ : [M $+\mathrm{H}]^{+}$calcd for $\mathrm{C}_{24} \mathrm{H}_{32} \mathrm{~N}_{9} \mathrm{O}_{10} \mathrm{~S}_{3}, 702.1461$; found, 702.1429; 
$(m / z):[\mathrm{M}+\mathrm{Na}]^{+}$calcd for $\mathrm{C}_{24} \mathrm{H}_{31} \mathrm{~N}_{9} \mathrm{NaO}_{10} \mathrm{~S}_{3}, 724.1277$; found, 724.1248 .

\section{2,4-bis(1-( $\beta$-D-galactopyranosyl)triazol-4-ylmethylthio)-6-} (1-( $\beta$-D-glucopyranosyl)triazol-4-ylmethylthio)-1,3,5triazine (17). A solution of the bis-Gal triazine cluster $\mathbf{1 6}$ (12.2 $\mathrm{mg}, 0.017 \mathrm{mmol}, 1$ equiv), $\beta$-D-glucopyranosyl azide (5.3 mg, $0.026 \mathrm{mmol}, 1.5$ equiv), $\mathrm{CuI}$ ( $1 \mathrm{mg}, 0.3$ equiv) and DIPEA $(0.043 \mathrm{~mL}, 15$ equiv) in DMF $(1 \mathrm{~mL})$ was heated under microwave irradiation for 15 minutes at $110{ }^{\circ} \mathrm{C}$. The reaction mixture was concentrated in vacuo and the residue was purified by $\mathrm{C} 18$ chromatography (Combiflash, Grace Reveleris C18 RP $4 \mathrm{~g}$ Cartridge, $\mathrm{H}_{2} \mathrm{O} / \mathrm{MeOH}$ gradient $)$. Yield $=30 \%$. $[\alpha]_{\mathrm{D}}-1.2(\mathrm{c}$ $\left.0.1, \mathrm{H}_{2} \mathrm{O}\right) ;{ }^{1} \mathrm{H}$ NMR (500 MHz, $\left.\mathrm{D}_{2} \mathrm{O}\right) \delta 8.20 \mathrm{ppm}(\mathrm{s}, 2 \mathrm{H}, \mathrm{Gal}$ H-d), 8.16 (s, 1H, Glc H-d), 5.70 (d, $J=9.2 \mathrm{~Hz}, 1 \mathrm{H}, \mathrm{Glc} \mathrm{H}-1)$, 5.65 (d, 2H, $J=9.2 \mathrm{~Hz}$, Gal H-1), 4.40 (s, 6H, H-b), 4.19 (t, $J=$ $9.5 \mathrm{~Hz}, 2 \mathrm{H}, \mathrm{Gal} \mathrm{H}-2), 4.09$ (d, $J=3.2 \mathrm{~Hz}, 2 \mathrm{H}, \mathrm{Gal} \mathrm{H}-5)$, 4.01-3.94 (m, 3H, Gal H-4, Glc H-2), 3.88 (dd, $J=9.3 \mathrm{~Hz}, J=$ $3.2 \mathrm{~Hz}, 2 \mathrm{H}, \mathrm{Gal} \mathrm{H}-3), 3.77$ (d, $J=12.1 \mathrm{~Hz}, 2 \mathrm{H}$, Gal H-6), 3.76 (d, $J=12.1 \mathrm{~Hz}, 2 \mathrm{H}, \mathrm{Gal} \mathrm{H}-6$ '), 3.74 (d, $J=11.6 \mathrm{~Hz}, 1 \mathrm{H}$, Glc H-6), 3.73 (d, $J=11.6 \mathrm{~Hz}, 1 \mathrm{H}$, Glc H-6'), 3.71-3.67 (m, 2H, Glc H-3, Glc H-4), 3.62 (t, $J=9.4 \mathrm{~Hz}, 1 \mathrm{H}$, Glc H-5); ${ }^{13} \mathrm{C}$ NMR (125 MHz, D $2 \mathrm{O}) \delta 178.7$ ppm (C-a), 144.4 (C-c), 123.4 (C-d), 87.1 (Gal C-1), 87.4 (Glc C-1), 78.9 (Glc C-4), 78.3 (Gal C-4), 75.9 (Glc C-3), 73.0 (Gal C-3), 72.3 (Glc C-2), 69.8 (Glc C-5), 68.6 (Gal C-5), 62.5 (Glc C-6), 60.8 (Gal C-6), 24.4 (Cb); HRMS-ESI $(m / z):[\mathrm{M}+\mathrm{Na}]^{+}$calcd for $\mathrm{C}_{30} \mathrm{H}_{42} \mathrm{~N}_{12} \mathrm{NaO}_{15} \mathrm{~S}_{3}$, 929.1916; found, 929.1947.

\section{Supporting Information}

Full 1D and 2D NMR spectra of compounds 1, 2, and 9-17; experimental procedures for ITC and biofilm inhibition studies, and for the synthesis of tris propargyl precursor $\mathbf{2}$, protected clusters 9-12, and 6- $C$-mannose cluster 15; additional DLS and ITC spectra, additional biofilm quantification information.

\section{Supporting Information File 1}

Experimental procedures, characterization checklist and NMR, DLS and ITC data.

[http://www.beilstein-journals.org/bjoc/content/ supplementary/1860-5397-10-206-S1.pdf]

\section{Acknowledgements}

Funding was provided by the French National Research Agency [ANR PCV08_322689 Glycoasterix], the COST actions CM1102 and BM1003, the Labex ARCANE (ANR-11-LABX003), the French Ministry of Higher Education and Research (MENSR), and the National Center for Scientific Research
(CNRS). MS gratefully acknowledges a $\mathrm{PhD}$ scholarship from the Faculy of Sciences, Carthage University. Emilie Gilloon and David Redelberger are thanked for outstanding technical assistance. All of the experimental work was performed by MS. The remaining authors contributed equally to this work.

\section{References}

1. Ramos, J.-L., Ed. Pseudomonas; Springer Science: New York, U.S.A., 2004; Vol. 1-3.

2. Bodey, G. P.; Elting, L. S.; Narro, J.; Koller, C.; O'Brien, S.; Estey, E.; Benjamin, R. J. Antimicrob. Chemother. 1993, 32, 141-152. doi:10.1093/jac/32.1.141

3. Mendelson, M. H.; Gurtman, A.; Szabo, S.; Neibart, E.; Meyers, B. R.; Policar, M.; Cheung, T. W.; Lillienfeld, D.; Hammer, G.; Reddy, S.; Choi, K.; Hirschman, S. Z. Clin. Infect. Dis. 1994, 18, 886-895. doi:10.1093/clinids/18.6.886

4. Wagner, V. E.; Iglewski, B. H. Clin. Rev. Allergy Immunol. 2008, 35, 124-134. doi:10.1007/s12016-008-8079-9

5. Lister, P. D.; Wolter, D. J.; Hanson, N. D. Clin. Microbiol. Rev. 2009, 22, 582-610. doi:10.1128/CMR.00040-09

6. Penha Escudeiro, B. M.; Baracho Marques, E. C., Eds. Pseudomonas Aeruginosa: Symptoms of Infection, Antibiotic Resistance and Treatment; Nova Science Publishers, 2012.

7. Imberty, A.; Wimmerová, M.; Mitchell, E. P.; Gilboa-Garber, N. Microbes Infect. 2004, 6, 221-228. doi:10.1016/j.micinf.2003.10.016

8. Cioci, G.; Mitchell, E. P.; Gautier, C.; Wimmerová, M.; Sudakevitz, D.; Pérez, S.; Gilboa-Garber, N.; Imberty, A. FEBS Lett. 2003, 555, 297-301. doi:10.1016/S0014-5793(03)01249-3

9. Garber, N.; Guempel, U.; Belz, A.; Gilboa-Garber, N.; Doyle, R. J. Biochim. Biophys. Acta 1992, 1116, 331-333. doi:10.1016/0304-4165(92)90048-Y

10. Diggle, S. P.; Stacey, R. E.; Dodd, C.; Cámara, M.; Williams, P.; Winzer, K. Environ. Microbiol. 2006, 8, 1095-1104. doi:10.1111/j.1462-2920.2006.001001.x

11. Mitchell, E.; Houles, C.; Sudakevitz, D.; Wimmerová, M.; Gautier, C.; Pérez, S.; Wu, M. A.; Gilboa-Garber, N.; Imberty, A. Nat. Struct. Mol. Biol. 2002, 9, 918-921. doi:10.1038/nsb865

12. Loris, R.; Tielker, D.; Jaeger, K.-E.; Wyns, L. J. Mol. Biol. 2003, 331, 861-870. doi:10.1016/S0022-2836(03)00754-X

13. Tielker, D.; Hacker, S.; Loris, R.; Strathmann, M.; Wingender, J.; Wilhelm, S.; Rosenau, F.; Jaeger, K.-E. Microbiology 2005, 151, 1313-1323. doi:10.1099/mic.0.27701-0

14. Mammen, M.; Choi, S. K.; Whitesides, G. M. Angew. Chem., Int. Ed. 1998, 37, 2754-2794. doi:10.1002/(SICI)1521-3773(19981102)37:20<2754::AID-ANIE2754>3 .0.CO;2-3

15. Lee, Y. C.; Lee, R. T. Acc. Chem. Res. 1995, 28, 321-327. doi:10.1021/ar00056a001

16. Lundquist, J. J.; Toone, E. J. Chem. Rev. 2002, 102, 555-578. doi:10.1021/cr000418f

17. Renaudet, O.; Roy, R., Eds. Multivalent Scaffolds in Glycoscience. Chem. Soc. Rev. 2013, 42, 4507-4844.

18. Roy, R. Curr. Opin. Struct. Biol. 1996, 6, 692-702. doi:10.1016/S0959-440X(96)80037-6

19. Mortell, K. H.; Gingras, M.; Kiessling, L. L. J. Am. Chem. Soc. 1994, 116, 12053-12054. doi:10.1021/ja00105a056

20. Roy, R.; Laferrière, C. J. Chem. Soc., Chem. Commun. 1990, 1709-1711. doi:10.1039/c39900001709 
21. Spaltenstein, A.; Whitesides, G. M. J. Am. Chem. Soc. 1991, 113, 686-687. doi:10.1021/ja00002a053

22. Chabre, Y. M.; Roy, R. Chem. Soc. Rev. 2013, 42, 4657-4708. doi:10.1039/c3cs35483k

23. Chabre, Y. M.; Roy, R. Adv. Carbohydr. Chem. Biochem. 2010, 63, 165-393. doi:10.1016/S0065-2318(10)63006-5

24. Turnbull, W. B.; Stoddart, J. F. J. Biotechnol. 2002, 90, 231-255.

25. Johansson, E. M. V.; Kadam, R. U.; Rispoli, G.; Crusz, S. A.; Bartels, K.-M.; Diggle, S. P.; Cámara, M.; Williams, P.; Jaeger, K.-E.; Darbre, T.; Reymond, J.-L. Med. Chem. Commun. 2011, 2, 418-420. doi:10.1039/c0md00270d

26. Johansson, E. M. V.; Crusz, S. A.; Kolomiets, E.; Buts, L.; Kadam, R. U.; Cacciarini, M.; Bartels, K.-M.; Diggle, S. P.; Cámara, M.; Williams, P.; Loris, R.; Nativi, C.; Rosenau, F.; Jaeger, K.-E.; Darbre, T.; Reymond, J.-L. Chem. Biol. 2008, 15, 1249-1257. doi:10.1016/j.chembiol.2008.10.009

27. Consoli, G. M. L.; Granata, G.; Cafiso, V.; Stefani, S.; Geraci, C. Tetrahedron Lett. 2011, 52, 5831-5834. doi:10.1016/j.tetlet.2011.08.142

28. Kadam, R. U.; Bergmann, M.; Hurley, M.; Garg, D.; Cacciarini, M.; Swiderska, M. A.; Nativi, C.; Sattler, M.; Smyth, A. R.; Williams, P.; Cámara, M.; Stocker, A.; Darbre, T.; Reymond, J.-L. Angew. Chem., Int. Ed. 2011, 50, 10631-10635. doi:10.1002/anie.201104342

29. Reymond, J.-L.; Bergmann, M.; Darbre, T. Chem. Soc. Rev. 2013, 42, 4814-4822. doi:10.1039/c3cs35504g

30. Sleiman, M.; Varrot, A.; Raimundo, J.-M.; Gingras, M.; Goekjian, P. G. Chem. Commun. 2008, 6507-6509. doi:10.1039/b814816c

31. Gingras, M.; Raimundo, J.-M.; Chabre, Y. M. Angew. Chem., Int. Ed. 2006, 45, 1686-1712. doi:10.1002/anie.200500032

32. Gingras, M.; Pinchart, A.; Dallaire, C. Angew. Chem., Int. Ed. 1998, 37, 3149-3151.

doi:10.1002/(SICI)1521-3773(19981204)37:22<3149::AID-ANIE3149>3 .0.CO;2-4

33. Bergamini, G.; Fermi, A.; Botta, C.; Giovanella, U.; Di Motta, S.; Negri, F.; Peresutti, R.; Gingras, M.; Ceroni, P. J. Mater. Chem. C 2013, 1, 2717-2724. doi:10.1039/C3TC00878A

34. Tucker, J. H. R.; Gingras, M.; Brand, H.; Lehn, J.-M. J. Chem. Soc., Perkin Trans. 2 1997, 1303-1308. doi:10.1039/a608455i

35. Chabre, Y. M.; Brisebois, P. P.; Abbassi, L.; Kerr, S. C.; Fahy, J. V.; Marcotte, I.; Roy, R. J. Org. Chem. 2011, 76, 724-727. doi:10.1021/jo102215y

36. Gingras, M.; Chabre, Y. M.; Roy, M.; Roy, R. Chem. Soc. Rev. 2013, 42, 4823-4841. doi:10.1039/C3CS60090D See for a review of sulfur-containing glycodendrimers.

37. Azev, Y. A.; Dülcks, T.; Gabel, D. Tetrahedron Lett. 2003, 44, 8689-8691. doi:10.1016/j.tetlet.2003.09.153

38. Tropper, F. D.; Andersson, F. O.; Braun, S.; Roy, R. Synthesis 1992, 618-620. doi:10.1055/s-1992-26175

39. Lafont, D.; D’Attoma, J.; Gomez, R.; Goekjian, P. G. Tetrahedron: Asymmetry 2011, 22, 1197-1204. doi:10.1016/j.tetasy.2011.06.027

40. Lee, B.-Y.; Park, S. R.; Jeon, H. B.; Kim, K. S. Tetrahedron Lett. 2006, 47, 5105-5109. doi:10.1016/j.tetlet.2006.05.079

41. Sabin, C.; Mitchell, E. P.; Pokorná, M.; Gautier, C.; Utille, J.-P.; Wimmerová, M.; Imberty, A. FEBS Lett. 2006, 580, 982-987. doi:10.1016/j.febslet.2006.01.030
42. Bernardi, A.; Jiménez-Barbero, J.; Casnati, A.; De Castro, C.; Darbre, T.; Fieschi, F.; Finne, J.; Funken, H.; Jaeger, K.-E.; Lahmann, M.; Lindhorst, T. K.; Marradi, M.; Messner, P.; Molinaro, A.; Murphy, P. V.; Nativi, C.; Oscarson, S.; Penadés, S.; Peri, F.; Pieters, R. J.; Renaudet, O.; Reymond, J.-L.; Richichi, B.; Rojo, J.; Sansone, F.; Schäfer, C.; Turnbull, W. B.; Velasco-Torrijos, T.; Vidal, S.; Vincent, S.; Wennekes, T.; Zuilhof, H.; Imberty, A. Chem. Soc. Rev. 2013, 42, 4709-4727. doi:10.1039/c2cs35408j

43. Soomro, Z. H.; Cecioni, S.; Blanchard, H.; Praly, J.-P.; Imberty, A.; Vidal, S.; Matthews, S. E. Org. Biomol. Chem. 2011, 9, 6587-6597. doi:10.1039/c1ob05676j

44. Cecioni, S.; Oerthel, V.; lehl, J.; Holler, M.; Goyard, D.; Praly, J.-P.; Imberty, A.; Nierengarten, J.-F.; Vidal, S. Chem. - Eur. J. 2011, 17, 3252-3261. doi:10.1002/chem.201003258

45. Cecioni, S.; Faure, S.; Darbost, U.; Bonnamour, I.; Parrot-Lopez, H.; Roy, O.; Taillefumier, C.; Wimmerová, M.; Praly, J.-P.; Imberty, A.; Vidal, S. Chem. - Eur. J. 2011, 17, 2146-2159. doi:10.1002/chem.201002635

46. Cecioni, S.; Lalor, R.; Blanchard, B.; Praly, J.-P.; Imberty, A.; Matthews, S. E.; Vidal, S. Chem. - Eur. J. 2009, 15, 13232-13240. doi:10.1002/chem.200901799

47. Otsuka, I.; Blanchard, B.; Borsali, R.; Imberty, A.; Kakuchi, T. ChemBioChem 2010, 11, 2399-2408. doi:10.1002/cbic.201000447

48. Pertici, F.; Pieters, R. J. Chem. Commun. 2012, 48, 4008-4010. doi:10.1039/c2cc30234a

49. Reynolds, M.; Marradi, M.; Imberty, A.; Penadés, S.; Pérez, S. Chem. - Eur. J. 2012, 18, 4264-4273. doi:10.1002/chem.201102034

50. Chabre, Y. M.; Giguère, D.; Blanchard, B.; Rodrigue, J.; Rocheleau, S.; Neault, M.; Rauthu, S.; Papadopoulos, A.; Arnold, A. A.; Imberty, A.; Roy, R. Chem. - Eur. J. 2011, 17, 6545-6562. doi:10.1002/chem.201003402

\section{License and Terms}

This is an Open Access article under the terms of the Creative Commons Attribution License (http://creativecommons.org/licenses/by/2.0), which permits unrestricted use, distribution, and reproduction in any medium, provided the original work is properly cited.

The license is subject to the Beilstein Journal of Organic Chemistry terms and conditions:

(http://www.beilstein-journals.org/bjoc)

The definitive version of this article is the electronic one which can be found at: doi:10.3762/bjoc. 10.206 